\title{
Oneiric Landscapes of Creation: Visions of Life and Death in José Gorostiza's Muerte sin fin ${ }^{1}$
}

In 2007, the Museo Soumaya in the Claustro de Sor Juana Inés de la Cruz in México City held the exhibition 'La muerte niña' in which there were displayed numerous affecting paintings and photographs recording the Mexican tradition of the artistic representation of dead children. The exhibition's curator explained that the practice of dressing up children as angelitos and immortalising their image was a way of affirming that they would bypass purgatory and go directly to heaven. The tradition was popular from the New Spain of the $16^{\text {th }}$ century through to $19^{\text {th }}$ century Mexico and continued to be observed in some villages to that day. As well as the overtly Christian associations with the passage to the afterlife, the practice recalled the Mesoamerican tradition of offering up dead children to the gods and, in this way, the exhibition underlined the syncretic dimension of the images (EFE, 2007).

The images are extraordinarily powerful and, to a modern eye, the later photographs are particularly arresting because they seem not so much to record the child's death as to perpetuate life in death. In many cases, the $19^{\text {th }}$ century images show the children, sometimes brothers and sisters together, dressed in their Sunday best apparently laid out in peaceful sleep or even posed as if still alive. It is clear that these children are dead. The viewer knows this from the context of the exhibition and the quality of unsettling perfection found in the inanimate. Yet, at the same time, meticulously composed in order to appear alive, we are overcome by the sense that, indeed, they might be. What the viewer experiences is a profound unconscious recognition of one's own mortality. The images give a perfect demonstration of Freud's notion of the unheimlich or the uncanny; not (as Freud explains) because of their ambiguity but because, as doubles, they rehearse within us the atavistic 
encounter between life and death (1955: 235). But the exhibition stages this encounter in an additional way, unexpected by the Western spectator and encapsulated in its title. As well as being a popular term given to this form of representation, la muerte niña is also a phrase that appears twice in José Gorostiza's poem of 1939, Muerte sin fin. Although the use of Gorostiza's poem was deliberately understated in the exhibition, the curators had arranged many extracts from that work alongside, and in dialogue with the images.

The term la muerte niña, without doubt, on the one hand implies the personal, human tragedy of the death of a young person yet, on the other and, in a sense largely lost to the West, overtly anthropomorphizes death, giving it an identity and an age. Whilst the Western viewer may flinch at death in the midst of life, the Mesoamerican spirit recognizes that death, as an active presence, forcefully inhabits life. From both perspectives, life and death confront one another but only in the latter do they intermingle in a process of exchange. It would seem that the curators of the La muerte niña exhibition saw precisely how Gorostiza's Muerte sin fin could help bring to light the divergent strands of Mexico's past that come together in the syncretism inherent in these images.

Muerte sin fin, a long poem divided into ten parts, is generally recognized as the greatest achievement of the writers associated with Contemporáneos generation, named after the literary magazine that ran for only three years from 1928 to $1931{ }^{2}$ The impact and longevity of the poem can be attributed to the way in which it combines a cinematic sensuality with a rarefied Hermeticism that is both philosophically and theologically profound. Stylistically, it is informed by the Contemporáneos group's admiration of the Hispanic baroque as well as European modernists such as Valéry and Eliot but mixes those high registers with popular 
vocabulary and dance forms. The poem speculates upon the relationship between the human and the divine against a backdrop that moves from creation to apocalypse. It contains little overtly indigenous subject matter, being more closely related to the Judaism of the Old Testament and the mysticism of the Kabbalah. ${ }^{3}$ Nevertheless, the imagery used by Gorostiza, as well as the central theme of the permanent drama of death, communicate the presence of a syncretic, Mesoamerican subtext in which monotheistic, and what we might term pagan attitudes to death, are fused.

The title of the poem immediately questions the Christian article of faith of everlasting life (John 3.36), not because it is overtly anti-Christian, but because it introduces the premise that death is not an end point to be overcome; it is rather a continuing and evolving action. Before Gorostiza enters into the complex exploration of the relationship between, life and death, he establishes, by implication, a model of death that recalls Octavio Paz's observations in The Labyrinth of Solitude:

Para los antiguos mexicanos la oposición entre muerte y vida no era tan absoluta como para nosotros. La vida se prolongaba en la muerte. Y a la inversa. La muerte no era el fin natural de la vida, sino fase de un ciclo infinito. Vida, muerte y resurrección eran estadios de un proceso cósmico, que se repetía insaciable. (1992: 63)

According to Paz, contrary to common Western perception, death is not opposed to life. Rather than the negation of being, death is a state and a phase that interconnects with life as a part of a cosmic system. Gorostiza's Muerte sin fin is a self-consciously syncretic and heterogeneous exploration of death but its essential dramatic premise remains close to the Mesoamerican view that death and life share a symbiotic and transformational relationship as elements in a continuum.

As Paz goes on to argue, life and death for the pre-Colombian Mesoamericans were essentially impersonal (1992: 64). The Western fashion for asserting ownership 
over life and death would have seemed an alien idea. But as incomprehensible as that concept might have been for them, its assumption underpins the Enlightenment and Western modernity and an artist of that tradition must meet it head on if he or she is to re-imagine death. Gorostiza does this immediately. In a poem named 'eternal death', he begins with a scene of personal birth:

Lleno de mí, sitiado en mi epidermis por un dios inasible que me ahoga, mentido acaso por su radiante atmósfera de luces que oculta mi conciencia derramada, mis alas rotas en esquirlas de aire, mi torpe andar a tientas por el lodo; lleno de mí -ahito- me descubro en la imagen atónita del agua, que tan sólo es un tumbo inmarcesible, un desplome de ángeles caídos a la delicia intacta de su peso, que nada tiene sino la cara en blanco (1988a: 65)

Immediately apparent in these lines are the mixed images of creation, mortality and evolution. Both Narcissus and Icarus are recalled as is an apparently deceitful god, whose status as creator is uncertain. The primordial wading through mud and the emphasis on water connote Darwinian science and the amniotic fluids of gestation and birth. More unusual than these elements in the context of the poem, however, is the subjective voice that opens, as if the beginning of the text were also the generation of an individual consciousness. These most regularly quoted first lines of the poem are not representative of its general tone because the first person voice only reappears sporadically throughout, not making a firm return until the final part. Gorostiza seemingly prepares the reader for a familiar meditation on personal anguish 
associated with being but thwarts expectations by quickly moving away from the first person. The fleeting subjectivity itself is also deceptive. In line with the Contempóraneos group's rejection of the centrality of the subject in Spanish American modernismo, there is no forthright yo in these lines. ${ }^{4}$ The object pronoun $m i ́$ that suggests its presence simultaneously threatens its integrity: 'Lleno de mí' seems to proclaim wholeness but implies a split in the subject confirmed by the various ancient and modern implications of self-recognition in a reflected image.

This fissuring and obscuring of individual identity is fundamental because it triggers an exploration of life and death that consistently avoids the self as explicit source or object of speculation. Seen in this way, life and death are not abstracted qualities defined by association with the individual but organic realities that exist beyond the human and inhabit it at will. Although the poem is affecting, it has little to do with the sentiment of personal reflection. The agony of the poet is not absent, but its nature and significance are recast within the primary context of a material universe in which the human mind and will are on a plane with atavistic, molecular forces. This impersonal attitude to life and death interconnects with several cultural and intellectual currents and although the least overt, by no means the lesser of those is the Mesoamerican belief outlined in Paz's words above.

Alongside this influence must be considered the more direct intellectual and aesthetic sources of the baroque and modernism that were important not just to Gorostiza but to the Contemporáneos group as a whole. As stated above, the group rejected the recent, ornate neo-classicism of modernismo but explored its presence in the early works of Latin American colonial literature. Most important for this study is the influence of the Spanish baroque poetry of Góngora and its legacy in Mexico, particularly in the work of Sor Juana Inés de la Cruz. ${ }^{5}$ A previous generation of 
Mexican writers, including Amado Nervo and Alfonso Reyes had already revived an interest in Sor Juana and Góngora that continued in Spain with the Generación de 27 and in Mexico with the Contemporáneos group (Oropesa, 2003: 2). Paz points out how Sor Juana's poetry differs from Góngora's in the intensity of its intellectual rigour, arguing that for Sor Juana poetic conceit is primarily a tool for conceptual exploration rather than aesthetic virtuosity (1983: 470).

It was this aspect of Sor Juana's work that appealed most to the Contemporáneos group, particularly as exemplified in her Primero sueño of 1692. Inspired by this model, Gorostiza constructs an oneiric landscape of animate and inanimate forms that comes within the purview of a detached perspective. Muerte sin fin therefore connects to a classical and neo-classical tradition that imagines an out-of body, speculative journey as a voyage depicted with a rich visual panorama. ${ }^{6}$ In this tradition, the essential characteristic of the dream as an interior, psychological experience is concretised into a physical and spatial experience in which the soul of the dreamer is afforded a privileged scopic dominion over an imagined landscape. There is a display of creative subjectivity inherent in Sor Juana's baroque exploration of human knowledge but the implied authority of the poetic voice should not be confused with egocentricity. Sor Juana uses the word yo only once at the end of the poem as the dreamer awakes and this alone is a daring aberration amongst the otherwise distanced and objective intellectual atmosphere. This tone of erudite speculation is carried over into Muerte sin fin but is realigned according to the twentieth-century contexts that dictate a more ambivalent and ambiguous voice. Where the classical and baroque poetic odysseys were intended as explorations of the scope of human knowledge, Gorostiza's neo-baroque modernism has essentially ontological concerns. Whereas, in Sor Juana's poem, God exists outside the frame as 
presumed architect of the Universe, in Muerte sin fin God is present as a tragic player and post-Nietzschean victim of the drama of life and death.

In his landmark study on Sor Juana, Paz explores the contemporary intellectual currents of Primero sueño and argues for a reconsideration of the poem's epistemology. Sor Juana's exploration, he argues, is founded upon the Aristotelian and Scholastic system of knowledge (1983: 493). However, the treatment of the dream in Primero sueño owes more to Hermetic thought and, in particular, the direct influence of the German Jesuit, Athanasius Kircher. ${ }^{7}$ Although a statement of faith, Paz contends that the dream represents an act of speculative knowledge rather than a display of certainty (1983: 499). What is more, the conclusion is uncertain. As argued above, God remains as anchor outside of the frame of the poem but the failure of Primero sueño's dreamer, who wakes up before a neat conclusion is reached, (Paz, 1983: 499) provides us with a conduit to Modernism and to Gorostiza:

Tampoco es una profecía de la poesía de la Ilustración sino de la poesía moderna que gira en torno a esa paradoja que es el núcleo del poema: la revelación de la no-revelación. En este sentido Primero sueño se parece a Le Cimetière Marin y, en el ámbito hispano, a Muerte sin fin y Altazor. (1983: 499)

Bound up in 'la revelación de la no-revelación' is a mystical, negative theology that informs Primero sueño and is central to Muerte sin fin. That poem, as I have discussed above in relation to the Mesoamerican attitude to death, turns upon the coexistence and codetermination of physically and logically opposed elements. Seen as such, death cannot be pure negation of life and it follows that the metaphysical or the interior does not simply oppose the physical or exterior world. Such a premise underpins the mystically inspired poetic philosophy of Gorostiza's work and helps us to understand his modernist version of Sor Juana's oneiric landscape. Gorostiza develops the physical, exterior panorama experienced by the soul of the dreamer in 
the baroque poem and recreates this as a landscape of a space that is simultaneously interior and exterior, metaphysical and physical, concrete and dream-like. Whilst not Surrealist in the properly generic sense, the poem shares the Surrealist sensibilities of the juxtaposition and correlation of opposites.

In Primero sueño, although it remains implicit, the connection to Hermetic thought without question lends a metaphorical significance to the vision of the dreamer linking it to the foundational mystical tenet that the universe is a product of a divine mind or dream. The soul's journey in Primero sueño connects back to Platonism and Neo-Platonism in which the human soul, as part of the world-soul, ensures a spark of the divine in the human. Muerte sin fin restages the idea of Creation as divine dream in such a way as to implicate inseparably the human but this time incorporating the disillusions of modernity:

Pero en las zonas ínfimas del ojo no ocurre nada, no, sólo esta luz -ay, hermano Francisco, esta alegría, única riente claridad del alma. Un disfrutar en corro de presencias, de todos los pronombres - ante turbios por la gruesa efusión de su egoísmode mí y de Él y de nosotros tres ¡siempre tres! mientras nos recreamos hondamente en este buen candor que todo ignora, en esta aguda ingenuidad del ánimo que se pone a soñar a pleno sol y sueña los pretéritos de moho, la antigua rosa ausente y el prometido fruto de mañana, como un espejo del revés, opaco, 
que al consultar la hondura de la imagen

le arrancara otro espejo por respuesta. (1988a: 69)

True to the exegetic language of classic mystical texts such as the Sefer Ha-Zohar of the Kabbalah, the poem develops ideas by the association of mystical tropes rather than systematic logic. ${ }^{8}$ Light is a classic way of referring to a divinity or emanations thereof and it is born in the eye clearly associated with divine intelligence via the third eye of Pythagorean and Platonic tradition. ${ }^{9}$ This light then sets the world in motion in the act of dreaming. However, whereas the reflection of the divine in the created lends a sense of potency to the dreamer in Primero sueño, Gorostiza emphasizes the implication that dreamer and dreamed become as one in an infinitely regressive mise en abîme. As Arturo Cantú points out, seen in relation to the development of the poem, the reference to Saint Francis is ironic (1999: 100). The doctrine of created life as the reflection of the creator is complicated by the implications of the line "nos recreamos hondamente'. ${ }^{10}$ Heretical to orthodox Christianity, the idea that God in Creation can be redeemed by man is a commonplace Judeo-Christian mystical premise. ${ }^{11}$ This sense is present in the poem but the centrality of death rather than life, coupled with the ironic treatment of the Trinity (' $i$ siempre tres!'), adds the scepticism of modernity.

Where Sor Juana's Primero sueño represents dream as an exterior, physical panorama, Muerte sin fin combines such a dreamscape with the contemporaneous implications of the unconscious and the psychological life that would have been alien to the baroque mind. The panorama of Muerte sin fin, whilst still conforming to many of the traits of the earlier work, suffers a collapse of geometrical integrity precisely because the dream of Creation in this context has been recast to reflect the relationship between interior and exterior developed for us by the neurological and 
psychological sciences and the art forms drawing on these. In theosophical mysticisms such as the Kabbalah, all of Creation was deemed to be inseparable from the godhead, and we can read this implication in the lines above. ${ }^{12}$ Creation - as dream - takes place within the 'zonas ínfimas del ojo' and, in the mystical context, is a clear implication of the all knowing eye of divine intelligence. ${ }^{13}$ However, the forceful agency of 'nos recreamos' dictates a double reading of the eye, now human as well as divine and not merely as a 'product' of the latter. The dream of Creation that takes place within firmly places the human as a simultaneous subject and object: at once 'internal' motivation and 'external' manifestation. The landscape that follows is both without and within the eye and is topologically paradoxical in the coexistence of interior and exterior space. Where the dream of Primero sueño holds a mirror up to Creation and reproduces a bird's eye view, Gorostiza's 'espejo del revés' reproduces the impossible spaces that can only arise when the specular is indistinct from the means of speculation.

The dream of Creation in the narrative dimension of Muerte $\sin$ fin is identified as the dream of God but in a poem in which nothing, not even God, can escape death, the identification between God and human is made clear. The objects of the divine dream that populate the new landscape are simultaneously posited as being of both divine and human creation: dream as life-giving incantation and dream as interior processor of the conscious and unconscious. The dream is relentlessly scopic:

Mas nada ocurre, no, sólo este sueño

desorbitado

que se mira a sí mismo en plena marcha;

presume, pues, su término inminente

y adereza en el acto

el plan de su fatiga, su justa vacación, su domingo de gracia allá en el campo, 
al fresco albor de las camisas flojas.

¡Qué trebolar mullido, qué parasol de niebla,

se regala en el ánimo

para gustar la miel de sus vigilas!

Pero el ritmo es su norma, el solo paso,

la sola marcha en círculo, sin ojos (1988a: 71)

The Elysian images of 'su justa vacación' connect to the familiar flora of the divine plan previously introduced elsewhere in the poem ('iplanta-semilla-planta!' / su tierna brisa / sus follajes tiernos') (1988a: 69) but attest to an everyday banality that marks them out as hollow, picture-postcard scenes rather than archetypes of Creation. The 'fresco albor de las camisas flojas' and the 'parasol de niebla' recall the condensed dream images of the unconscious mind's eye more than divine architecture. Reminiscent of Surrealism's simultaneous delight in and attack on the visual, this panorama, produced by a repetitive, circular rhythm owes as much to blindness as it does to sight. These are images of Creation that perpetually hover between darkness and light and between life and death, suspended in the same uncertain realm witnessed by the viewer of the images of la muerte niña and encompassing both the psychological and mythopoetic dimensions captured in that exhibition. The space is uncertain, shifting between the tactile physicality of the neo-baroque excess of "este sueño desorbitado' and the evanescent forms of mind or spirit that give only the impression of extension.

This is the textual representation of space that Gorostiza achieves in Muerte sin fin but the above description risks simplification by defining the exterior and interior in a neat relationship with life and death. As I argued in the introduction, the Mesoamerican mind saw death and life as interconnected in a transformational relationship. In such a process, where life and death are overlaid, the tropic 
associations between substance and life, on the one hand, and ethereality and death, on the other, are reconfigured and blurred. To argue that such a binary does not exist for Christianity is incorrect because death, vanquished, for some, by the afterlife, retains its sting as the Other. The psychological dimension of the poem also troubles the binary relationship, for blindness, although figured as a product of wounding (again we are reminded of Freud's unheimlich and the Surrealist resonances), implies a dimension of insight or secret knowledge.

Above all else, the representation of space in Gorostiza's poem is an abstract landscape of pure transformation which is simultaneously physical and, in the most inclusive sense, metaphysical. Neither God nor the voice of the poet take centre stage but exchange places in a substitution of equal agency which is equally limited. The repeating, principle image Gorostiza uses for transformation is 'un vaso de agua' in which being is figured as an amalgamation of the glass as form and the water as substance. The coming together of the water and the glass is a clear image of Creation where brute matter is fixed into a finite form. With multiple theological and philosophical allusions, the glass and water merge dialectically in the formation of a triad, the glass of water becoming a third entity that incorporates and subsumes form and matter:

En la red de cristal que la estrangula, el agua toma forma, la bebe, sí, en el módulo del vaso, para que éste también se transfigure con el temblor del agua estrangulada que sigue allí, sin voz, marcando el pulso glacial de la corriente.

Pero el vaso

- a su vez-

cede a la informe condición del agua 
a fin de que - a su vez — la forma misma,

la forma en sí, que está en el duro vaso

sosteniendo el rencor de su dureza

y está en el agua de aguijada espuma

como presagio cierto de reposo,

se pueda sustraer al vaso de agua (1988a: 81)

In the image of the glass of water, the inception of life is figured as a metamorphic exchange of interior and exterior space which Gorostiza puts to work with multivalent significance. The dreamscape, as extensive panorama and intensive psychological 'work' is condensed metaphorically in the process where the combination of form and substance necessitates their transformation. Whether we read the process as the mystical drama of Creation and apocalypse, the organic cycle of birth and decay, the intimate yet mysterious relationship between the conscious and the unconscious or the precarious generation of meaning in poetry, ${ }^{14}$ the exchange and tension between interiority and exteriority is Gorostiza's primary trope.

The trope itself works to unravel the stability of the extensive and the intensive as oppositional qualities. The revealed and the un-revealed, the organic and the inorganic, the spirit and matter are indivisible at the instant in which, together, they form life. But life, as we are reminded by the 'presagio cierto de reposo', is constantly accompanied by death. In the beginning of the long, penultimate verse that narrates the apocalyptic returning of all life to its source, Gorostiza sets out this paradox. The water: boundless, heterogeneous matter laments its entrapment; and the glass: eternal homogeneous essence, resents the association with a contents. The result is disintegration and an end of being:

un instante, no más, no más que el mínimo perpetuo instante del quebranto, 
cuando la forma en sí, la pura forma,

se abandona al designio de su muerte

y se deja arrastrar, nubes arriba,

por ese atormentado remolino

en que los seres todos se repliegan

hacia el sopor primero,

a construir el escenario de la nada. (1988a: 81)

These lines make it clear that the end of being is nothing more than being itself. The explosion of the glass of water takes place as a 'perpetuo instante': a permanently accruing present without history or future but which, in its transformation, contains the seed of the conditions that precede and follow it. Death is not a state reached once being is over but is a perpetual and dramatic condition of being that shares a transmutational relationship with life. Death is figured as eternal in the poem, because all being is a movement towards death and simultaneously the movement of death. ${ }^{15}$

Following the example of Primero sueño, Gorostiza's landscape of transformation sets out to be a vision of life but becomes a meditation on death, contending that the two are codeterminate. The poem's representation of the human dimensions of death is ambiguous. Whilst it is in no sense elegiac, neither does Muerte sin fin lament the cruelty of death from the perspective of the individual. Death's inevitability is not without a sense of horror but that impact is outweighed by the essentially impersonal way in which the poem presents death as an atavistic force inseparable from life. The overwhelming power of death is not celebrated but is confronted met with face to face. This tone, as I argued above, echoes the indigenous Mesoamerican attitudes present in the tradition of la niña muerte and reflects the impression that the exhibition leaves on the spectator. The restaging of life in death in those images loses nothing of the affecting power of death but results in a form of 
confrontation between life and death that the modern Western subject will rarely experience. For all of its challenging theological and philosophical content, the affective impact of Muerte sin fin is of equal importance.

To fully understand fully Gorostiza's conceptualisation of death, the poem also needs to be read alongside cotemporary, Western modernisms. Commenting on Gorostiza's essay of 1955 'Notas sobre poesía', Juan Rulfo noted that, although Gorostiza was not familiar with Rilke, the similarity between their ideas and attitudes was striking (1988: 350). Die Sonette an Orpheus, particularly when read alongside Maurice Blanchot's work on Rilke, makes a revealing companion to Gorostiza's poem. In Sonnet 13 of the Second Part, Rilke writes:

Be forever dead in Eurydice-, and climb more singingly, climb more praisingly, back into the pure relation.

Here, among the vanishing, $b e$, in the realm of decline be a ringing glass that shatters even as it rings.

$\mathrm{Be}$ - and know as well the terms of nonbeing, the infinite ground of your inmost vibration, so that, this once, you may wholly fulfill them. (2004: 85)

Down to the almost identical image of the ringing glass, the similarities to Gorostiza's conception of death are startling. As Blanchot argues, the Duineser Elegien and Die Sonette an Orpheus mark the phase when Rilke understands death in a new way:

And so the concern that will bit by bit displace the center (sic) of Rilke's thoughts is confirmed: will we continue to regard death as the foreign and the incomprehensible, or will we learn to draw it into life, to make of it the other name, the other side of life? (1982: 129)

Death in the Sonnets, argues Blanchot, is a seizing of opportunity and a realm of metamorphosis. Orpheus's profound legacy, he argues, is not his survival of the 
underworld, but his role as intermediary between life and death and, more importantly, his desire to see Eurydice in death rather than return her to the living (1982: 172). Orpheus's act of turning towards death becomes, for Rilke, the authentic path to transmutation (1982: 146-147). To face death is neither to accept oblivion nor assert immortality but to recognize the eternity of dying and to become it. Only in dying does the material become immaterial, the visible invisible. Only there is the metamorphic exchange between inside and outside that Blanchot sees in Rilke and that Gorostiza explores in Muerte sin fin with the figure of the glass of water (1982: $157)$.

The affinity that Muerte sin fin has with Rilke's Die Sonette an Orpheus is affirmed in the shared concentration on physical existence. Blanchot writes of Rilke:

It might well be said that often when he thinks of the word absence, he thinks of what the presence of things is for him: he thinks of that being-a-thing, humble, silent, grave obedience to the pure gravity of forces which is repose in the web of influences and the balance of movements. (1982: 151)

If Blanchot affirms that Orphic space in Rilke's poetry is the text's desire to disappear in the turning towards death, these words remind us that the vibration of the internal and the invisible is only experienced properly in the exterior, visible world. Gorostiza's mystical, neo-baroque imagining of Creation returning to the origins has overt connections to the Orpheus myth and, like Rilke's Sonnets is a vision of the transformation of death that refuses to dwell on the ego of the poet. In both works, death is not depicted in quiet contemplation as discrete and intangible. It is to be experienced as a force amongst the living that interpenetrates the exterior and interior worlds. This, for Blanchot, is the definition of Orphic space:

the space which is nothing but outerness and which is nothing but intimacy, superabundance where things do not limit or infringe upon 
each other, but in their common unfurling make room instead of taking it up, and constantly "transform the outside world... into a handful of Within". (1982: 157)

Orpheus's transformation of death, 'which makes death the infinite movement of dying'(1982: 157), does not take place in space so much as it transforms space in order to make it at once intensive and extensive, actual and virtual. Gorostiza's neobaroque landscape is formally distinct from that of Rilke's Sonnets in many respects but his metamorphic configuration of the internal and external, driven by 'the infinite movement of dying' precisely recalls Blanchot's reading. Gorostiza's version of death, so closely resembling Rilke's by bringing death back into the material world, is essentially modernist in its rejection of Capitalism's perceived turning away from death.

If the attitudes towards death in Die Sonette an Orpheus and Muerte sin fin resemble one another intimately, the tones of the poems are very different. Where Rilke's tone is celebratory in the revelations afforded in the drawing close to death, Gorostiza's is closer to resignation. The differences without doubt have several explanations but important amongst these, I would argue, is the latent, syncretic attitude to death in Mexico that informs Gorostiza's work. Blanchot refers to death as 'organic' in Rilke's late poetry but argues that, for Rilke, it is not enough to accept the 'biological reality' (1982: 125). Instead, the poet must actively encounter 'death's being' (1982: 125) by achieving the immanence of death: 'There is, then, a double task: I must die a death which does not betray me, and I myself must die without betraying the truth and the essence of death' (1982: 128). In Muerte sin fin, Gorostiza goes far beyond a contemplation of organic death in the Western sense but the agency of the poetic voice is, in comparison, ambivalent in the face of a death that, more than 
an essence or being, is identified through personification. Death, la muerte niña, transforms into something (someone) altogether more alluring yet sinister.

In the final verse, Gorostiza abandons the high registers of philosophical speculation and mythopoetic narrative for a ludic, popular dance form ending with the following:

Desde mis ojos insomnes

mi muerte me está acechando, me acecha, sí, me enamora con su ojo lánguido.

¡Anda, putilla del rubor helado, anda, vámonos al diablo! (1988a: 88)

The forceful poetic voice of the beginning of the poem finally returns at the end and hands itself over to infinite death. ${ }^{16}$ Where Rilke's voice offers itself to death in the certainty of new knowledge and the promise of revelation, Gorostiza's is delivered into the hands of an irresistible, seductive force. The infinite transformation of death in life is present in Muerte sin fin and so too is Rilke's modernist impulse to reimagine death as something other than a terrifying void. However, these are balanced against a cultural context in which death has meanings quite different from the JudeoChristian West. As Blanchot affirms, death is impersonal in Rilke's late poetry because to experience the transformation of death one must submit to its essence (1982: 149). This attitude takes Rilke's poetry towards the impersonality of death in the Mesoamerican tradition but it retains a human will that is alien to Paz's discussion of death cited above. In the Mesoamerican spirit and in Muerte sin fin death is the agent: impersonal because it belongs to nobody but personified as wilful and desiring. More overtly than at any other moment in the poem, in these last lines we are presented with a personification of death that returns us to la muerte niña, the infant 
death of Mexican tradition. In a further, final act of transformation, la muerte niña changes from innocent virgin into lascivious prostitute. Gorostiza reaffirms being as metamorphosis in death and, in the first two lines, vividly conjures the images of death in life/life in death of the Mexico City exhibition. His poem however, recasts the syncretism away from the orthodox chasteness of Christianity and the echoes of the Virgin Mary/Virgen de Guadalupe towards the aggressive sexuality of the Mexican La Chingada. ${ }^{17}$ In its naming, death is objectified by Gorostiza in a way that recalls Mesoamerican beliefs and in this he differs markedly from Rilke. In both cases, death remains thoroughly impersonal and a process of transformation: for Rilke as an infinite 'inmost vibration' and, for Gorostiza, as the Chaos of an endless rebirthing. Although Rilke relegates the role of the ego in the Sonnets, we are left with a perspective of a poet attempting to understand the nature of his being. The final lines of Muerte sin fin undercut the ontological speculation that has gone before and all attempts at understanding appear to be subordinated to inhuman forces. Although the baroque excess has disappeared, the scopic landscape remains, as does its spatial ambiguity. 'Desde mis ojos insomnes', death approaches simultaneously from within and from without, itself figured as an eye returning the gaze. Both theological, allseeing eye and portal to the unconscious, it brings into view the extensive world and encloses within the intensive. In so doing, it beckons not an end but the unknown and erotic realms of transformation between physical and metaphysical space.

\section{BIBLIOGRAPHY}

Allen, M.J.B. 1982. Marsilio Ficino on Plato's Pythagorean Eye. MLN, 97 (1): 171182.

Blanchot, M. 1982 [1955]. The Space of Literature, trans. by A. Smock. Lincoln and London: University of Nebraska Press. 
Breton, A. 1955 [1932]. Les Vases communicants. Paris: Gallimard.

Bucher, R.J. 2005. Saint Francis of Assisi. In: L. Jones, ed. Encyclopedia of Religion, vol. 5. Farmington Mills, Mi.: Thomson Gale, pp. 3184 - 3185.

Caisso, C. 2000. "De inmundos calabozos, de elevadas galerías aéreas": José Gorostiza. Cuadernos Americanos, 82: 131-43.

Cantú, A. 1999. En la red de cristal. México City: Universidad Autónoma Metropolitana.

Coroleu, A. 2007. A Note on Sor Juana Inés de la Cruz's Primero sueño. In: J. Andrews and A. Coroleu, eds. Mexico 1680: Cultural and Intellectual Life in the 'Barroco de Indias'. Bristol: HiPLAM, pp. 130-139.

Cruz, J.I. de la (sor). 1996 [1692]. Primero sueño. In: A.P.A. Adam. El precipicio de Faetón: Nueva edición, estudio filológico y comento de Primero sueño de Sor Juana Inés de la Cruz. Frankfurt \& Madrid: Vervuert/Iberoamericana, pp. 28104.

EFE. 2007. La muerte niña. El Universal [online] 27 March [accessed 4 February 2011]. Available at <http://www.eluniversal.com.mx/guiaocio/356648.html>

Escalante, E. 2001. José Gorostiza: Entre la redención y la catástrofe. Mexico City: Ediciones Casa Juan Pablos; Villahermosa: Universidad Juárez Autónoma de Tabasco; Durango: IMAC; Mexico City: UNAM.

Freud, S. 1955 [1919]. The Uncanny. In: J. Strachey ed. The Standard Edition of the Complete Psychological Works, vol. 17, trans. by J. Strachey. London: Hogarth, pp. 217-56.

Gorostiza, J. 1988a [1939]. Muerte sin fin. In: E. Ramírez, ed. José Gorostiza, Poesía ${ }^{18}$ y poética. Madrid: Colección Archivos, pp. 63-88.

Gorostiza, J. 1988b [1955]. Notas sobre poesía. In E. Ramírez, ed. José Gorostiza, Poesía y poética. Madrid: Colección Archivos, pp. 144-52.

Mansour, M. 1988. El Diablo y la poesía contra el tiempo. In E. Ramírez, ed. José Gorostiza, Poesía y poética. Madrid: Colección Archivos, pp. 221-253.

Oropesa, S.A. 2003. The Contemporáneos Group. Austin: University of Texas Press.

Paz, O. 1983. Sor Juana Inés de la Cruz o las trampas de la fe, 3rd ed. Mexico City: Fondo de Cultura Económica.

Paz, O. 1992 [1981]. El laberinto de la soledad, Postdata \& Vuelta a El laberinto de la soledad. Mexico City: Fondo de Cultura Económica.

Ramírez, E. ed. 1988. José Gorostiza, Poesía y poética. Madrid: Colección Archivos. 
Rilke, R.M. 2004 [1923]. Sonnets to Orpheus, bilingual ed., trans. by E. Snow. New York: North Point Press.

Rilke, R.M. 2005 [1923]. Duino Elegies and The Sonnets to Orpheus, bilingual ed., trans. by A. Poulin Jr. New York: Mariner Books.

Rubín, M.S. 1966. Una poética moderna: Muerte sin fin de José Gorostiza. Mexico City: UNAM.

Rulfo, J. 1988 [1980]. En su discurso de ingreso a la Academia Rulfo recordó a Gorostiza. In: E. Ramírez, ed. José Gorostiza, Poesía y poética. Madrid: Colección Archivos, pp. 348-350.

Scholem, G. 1978. Kabbalah. New York: Meridian.

Scholem, G. 1995 [1941]. Major Trends in Jewish Mysticism. New York: Schocken.

Sheridan, G. 1985. Los contemporáneos ayer. Mexico City: Fondo de Cultura Económica.

Yates, F.A. 1964. Giordano Bruno and the Hermetic Tradition. Chicago and London: The University of Chicago Press.

\footnotetext{
${ }^{1}$ The author would like to thank the University of Leicester for the study leave during which research for this article was carried out.

${ }^{2}$ For a detailed study of the figures and contexts related to Contemporáneos group and magazine, see Guillermo Sheridan (1985).

${ }^{3}$ Mónica Mansour has discussed the presence of the Kabbalah in Gorostiza's poem at length (1988: 221-253).

${ }^{4}$ According to Evodio Escalante, this is one of the four defining characteristics of the movement of which Gorostiza was a part (2001: 47).

5 A number of critics have discussed the similarities between Muerte sin fin and Primero sueño including José Lezama Lima. For a discussion of this see Claudia Caisso (2000: 134, n. 8). Mónica Mansour mentions the connection and also cites Mordecai S. Rubín’s study (1988: 221-222 \& 221, n. $4)$.

${ }^{6}$ Alejandro Coroleu considers the history of this tradition in a study that argues for a reconsideration of the standard critical evaluation of Sor Juana's use of the dream in Primero sueño (2007: 130-139).

${ }^{7}$ Paz's work on Sor Juana makes a great many references to Kircher and the importance of his work for Sor Juana and Primero sueño (1983: 475-480).

${ }^{8}$ For a discussion of the literary character of the Zohar, see Gershom Scholem (1995: 157-158).
} 
${ }^{9}$ For a discussion of the history of the development of this tradition and its revival in Renaissance NeoPlatonism, see Michael J.B. Allen (1982: 171-182).

${ }^{10}$ On the Franciscan doctrine see Raymond J. Bucher (2005: 3185).

${ }^{11}$ For a discussion of this in relation to the early Spanish Kabbalah, see Scholem (1978: 166) and for its adaptation in the Christian Kabbalism of the Renaissance see Frances A. Yates on Pico della Mirandola (1964: 84-116).

${ }^{12}$ Early European Kabbalists devised the concept of the Ein-Sof as a term relating to the infinite godhead within which all Creation took place (Scholem, 1978: 88-91).

${ }^{13}$ Divine intelligence is a primary principle of Creation in the Kabbalah and an element that appears prominently in the poem before the act of creation in this verse.

${ }^{14}$ This is an aspect of Muerte sin fin which I will not discuss at length in this study. Gorostiza himself, albeit not overtly, points towards the possibility of reading the poem in this way (1988b: 144-152). Referring to the revelatory meaning of which poetry is capable, he says: '[b]ajo el conjuro poético la palabra se transparenta y deja entrever, más allá de sus paredes así adelgazadas, ya no lo que dice, sino lo que calla' (1988b: 145). He then reminds us of the fragility of verse: ‘[p]orque la poesía — no la increada, no, la que ya se contaminó de vida — ha de morir también’ (1988b: 152).

${ }^{15}$ An understanding of the interconnection and transformation of conscious and unconscious space in Gorostiza's poem might be developed further in conjunction with André Breton's Les Vases communicants of 1932. Direct influence of this text on Gorostiza may prove impossible to find but Breton was a prominent figure for the Contemporáneos group. He spent time in Mexico in 1938 and in the same year Diego Rivera made a print named after Breton's book. Breton's image of the exchange of liquid between vessels via a 'tissu capillaire' as a metaphor for the fluid interconnection of the interior and exterior worlds would seem to speak directly to the central motif of Muerte sin fin (1955: 161).

${ }^{16}$ Blanchot also reminds us that the phrase 'die unenlichen Toten' appears at the end of Rilke's Duineser Elegien (1982: 149).

${ }^{17}$ For Octavio Paz's seminal discussion of the cultural significance of this figure, see 'Los hijos de la Malinche' (1992: 78-107). 